\title{
Explaining Brexit, Post-Brexit Foreign Strategies of the UK and the UK-EU Relations
}

\author{
Yichen $\mathrm{Jia}^{1, *}$ \\ ${ }^{1}$ Shishi High School, Chengdu, Sichuan, China \\ ${ }^{*}$ Corresponding author. Email: guanghua.ren@gecacademy.cn
}

\begin{abstract}
The essay aims to explore why the United Kingdom has left the European Union and then the impact of the Brexit on the UK foreign strategies and the EU-UK relations. After the Brexit, the United Kingdom redefined its position in the world.The United Kingdom's diplomatic strategy and diplomatic focus have also been changed accordingly. "Global Britain" has become an important diplomatic strategy of the United Kingdom, and therefore, the relationship between the UK and the EU is also changing. The essay uses the case study method. Through the case study of the UK, the essay hopes to have broader lessons of what can drive a European Union member-state to leave the European Union and what is likely to be the subsequent consequence on the foreign policies of the state. The result revealed that three reasons drive the UK to leave the EU: the problems of social welfare and employment, the lack of European identity, and the UK party politics. The study found that even if Brexit impacted the United Kingdom and the European Union, the UK and the EU in general still hope to establish a new type of mutually beneficial relationship. The "Global Britain" strategy will be further strengthened in terms of diplomatic strategies, and more attention will be paid to the relationship between the Commonwealth and the UK and the US-UK relations. As a result, the UK and the EU will establish a new type of interdependent relationship. In conclusion, the essay deepens our understanding of the foreign strategy of the UK, the EU-UK relationship, the impact of Brexit. Moreover, the essay can be useful to the UK government to adjust the foreign policies. It can provide advice to international business people and students to invest and study in the UK. Admittedly, the essay is limited because it does not discuss concrete ways of cooperation between the UK and other countries. Further studies can look into the specific cooperation mode between the UK and the EU, the US, the Commonwealth countries and developing countries.
\end{abstract}

Keywords: Brexit, Global Britain, UK-EU Relations, the European Union, Splendid Isolation

\section{INTRODUCTION}

The essay's research questions are why Brexit has happened and what is the impact of Brexit. The existing research often focuses on the reasons for Brexit and the EU and the UK's policy on Brexit. There is a relative lack of analysis and prediction of the UK-EU relationship and its future development. This article will combine basic facts and the impact of Brexit. The article also focuses on analysing Britain's post-Brexit diplomatic strategy and the trend of British-European relations. This question is complex and unique because the exit from the EU of its member-state happened for the first time, and there are multiple reasons and multi-layer impacts.

Britain and the European Union are among the most concerned countries and national alliances respectively in the world. Brexit has attracted the world's attention, and it has also brought a huge impact on the United Kingdom, the European Union and other countries. In 2016, the Cameron government held a referendum. On June 23, the Brexit referendum ended, and the Brexit faction narrowly won. After the referendum results were announced, a large number of British people were not satisfied and held demonstrations and petitions in hopes of a re-referendum. The government rejected them because the results of the referendum should be respected. From June 23, 2016, to January 31, 2020, after protracted negotiations between the United Kingdom and the European Union, the United Kingdom has truly officially left the European Union.

This essay will focus on the United Kingdom. The United Kingdom is a unique case because it is the first country to leave the European Union so far. However, this case applies to other EU member countries that may 
have the potential willingness to leave the European Union.

This research matters because it will help reorganize the relationship between the United Kingdom and the European Union, the impact of Brexit on the United Kingdom, the European Union and other countries in the world. The research also provides a deep understanding of the future interdependent and new cooperative relations between the European Union and the United Kingdom. Finally, it can help to provide policy recommendations to the UK and EU governments.

The essay is divided into several sections. After the introduction, the second part analyzes the reason for Brexit from the perspectives of British exceptionalism, national culture and party politics based on the factual background and existing literature. The third part discusses the changes in British diplomatic strategy after Brexit. It presents the "Global Britain" diplomatic strategy proposed by the United Kingdom after the formal decision to leave the European Union. The third part also analyzes the trend of the relationship between the Commonwealth, the United Kingdom and the United States, and the United Kingdom and other countries. The fourth part analyzes the trend of British-European relations after Brexit, including the historical evolution and current situation of British-European relations and the interdependence between Britain and the European Union and their strategic choices. The fourth part also predicts the future direction of the relationship between Britain and Europe from the following three aspects: Britain's attitude towards the European Union, the cultural ties between Britain and Europe, the attitude of the United Kingdom and the European Union on Brexit negotiations and the content of the treaty reached. The final conclusion will summarize the whole article and provide the direction of the studies.

\section{REASONS FOR BREXIT}

On January 23, 2013, the leader of the Conservative Party-Cameron gave a speech on the prospects of the relationship between the United Kingdom and the European Union. In the speech, he promised to the British public that if he won the general election, he would hold a referendum on Brexit. In the following elections, in 2015, the Conservative Party won a big victory. Cameron held a referendum on Brexit ahead of schedule because of pressure from civil activities and the UK Independence Party.

On June 23, 2016, the Brexit referendum was held. The European Union (withdrawal) Act 2018 was thus promoted. After a series of negotiations with the European Union, the United Kingdom officially left the European Union at $11 \mathrm{pm}$ on January 31, 2020. This also signifies that the UK will no longer be a member of the European Union from now on but as an independent country to interact with countries around the world. The provisions in the treaties between the United Kingdom and the United Nations, NATO and other organizations need to be re-signed. Britain "takes back its sovereignty", but there are still many challenges ahead. Generally speaking, Brexit is mainly caused by the following three reasons [1].

\section{The Result of Brexit Referendum}

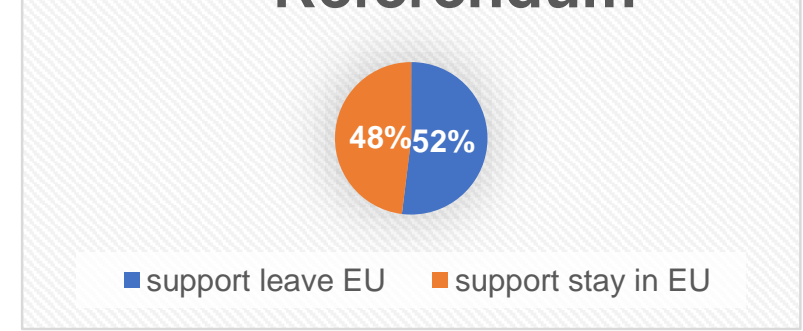

Figure 1. the result of the Brexit referendum [2]

\subsection{An Exceptionalism-based Approach}

Although the result of the Brexit referendum was unexpected, it is also reasonable. Britain has always advocated British exceptionalism and does not regard itself as an EU part but a sovereign country independent of the EU. Although joining the EU has allowed the UK to obtain many benefits, such as free trade regulations within the EU, it has also brought some problems and burdens to the UK.

The EU labor mobility policy within the EU has led to a large number of EU citizens coming to the UK for employment. Britain has to provide social welfare for these EU citizens. This undoubtedly increased the financial burden of the UK. The high unemployment rate and the serious gap between the rich and the poor in the UK in recent years have made people dissatisfied with the EU labor mobility policy. Some Britons believe that these EU citizens have robbed the British natives of their jobs. The EU's own situation is even more worrying. With the outbreak of the debt crisis in recent years, the EU has shifted more power to Brussels. This has strengthened Britain's suspicion of the EU. In addition, the EU is also unpopular in its approach to economic and refugee issues. Public opinion surveys show that people in EU countries are dissatisfied with the EU's handling of these issues. This is also one of the reasons why the British people's support for staying in Europe has fallen $[3,4]$.

\subsection{Lack of European Identity}

The establishment of the European Union does not mean that the identity of European citizenship is established in all EU countries, especially in the United Kingdom. Based on the special geographical nature of 
Britain as an island country and its cultural and empire complex that is completely different from that of the European continent, the British generally have a low degree of recognition of European citizenship. This has also led to their lack of fundamental nostalgia for the EU, especially for the elderly and low-income people who stay in the country all year round. Their intention to leave the European Union is generally obvious because the EU's labor mobility policy has brought panic to the elderly. They worry that the British culture and demographic structure will change as a result, and they are the people who have witnessed the glorious period of the British Empire. Therefore, they generally hope that they can take back their sovereignty from the EU and reproduce the empire's glory. For low-income groups who do not have passports and stay in the country all year round, they often do not work in other EU countries or engage in cross-border trade. This means that they have not gained much benefit from joining the EU. However, people from EU countries have deprived them of their few job opportunities, making them generally support Brexit $[5,6]$.

\subsection{Party Politics Explanation}

From a political perspective, the incident of Brexit was first proposed by Cameron, the leader of the Conservative Party at the time. European skepticism prevailed in the UK at that time. To attract votes to win the general election, Cameron promised the public that he would immediately hold a referendum on Brexit once he won the general election. In fact, the Conservative Party has long been divided into two factions of moderate Euro-skeptics and more radical Euro-skeptics on the EU issue. Cameron's move can also ease the contradictions within the party. Cameron is bound to hold a referendum on Brexit after winning the general election to exercise his commitment to the British public. However, as a moderate Euro-skeptic, he actually does not want Britain to truly leave the European Union. In fact, he hopes to use the results of the Brexit referendum to further bargain with the EU and strive for greater benefits for Britain in the EU. Moreover, it can also promote the reform of the European Union. In fact, his actions also happened to provide a voice for those who are dissatisfied with the EU in the UK. As a result, Britain finally left the European Union and launched a series of protracted negotiations with the European Union [7, 8].

\section{BRITISH DIPLOMATIC STRATEGIES AFTER BREXIT}

After Brexit, the United Kingdom lost its status as a member state of the European Union. However, it was no longer bound by the European Union at the political, diplomatic, economic and trade levels and gained more independence and freedom. At this time, the UK will continue to maintain the various cooperation and exchanges between the UK and the EU as much as possible. Britain also took this opportunity to focus more on the world outside the EU. It is indispensable for Britain to maintain the special relationship between the United Kingdom and the United States and the ties between the Commonwealth countries and the United Kingdom. Also, more expansion of economic and political exchanges with emerging economies can promote the prosperity of the British economy. Therefore, after Brexit, Britain will adopt a new type of foreign policy. Britain intends to take back its sovereignty and establish an image of a more confident, global, and outward-looking Britain on the world stage without the intervention of the European Union $[9,10]$.

\subsection{Strengthening Friendly Relationship with the US}

The ties between Britain and the United States in history and the appreciation of each other's culture have enabled a strong bond between the two countries. After Brexit, the then British Prime Minister Theresa May actively visited the United States and called for "defending Western values" with the United States. The United Kingdom and the United States continue to share intelligence between the two sides. They hope to strengthen cooperation between the British Government Communications Department (GCHQ) and the United States National Security Agency. Britain hopes to work with the United States to maintain the current international order, especially the status of the United Nations, the WTO. The United Kingdom aims to cope with the Islamic State (anti-terrorism) threats and cyberspace security issues with the United States and push the United States to continue to support NATO. The United Kingdom also hopes that the United States can work with Western countries on the North Korean issue to exert greater pressure on North Korea and contain Russia's threat to Europe. In terms of economy and trade, the United Kingdom seeks to promote the signing of the Anglo-U.S. free trade agreement, enhance exchanges between small and medium-sized enterprises of the two sides, and strengthen cooperation in aviation, finance and other fields. Therefore, the post-Brexit United Kingdom has strengthened the relationship with the US in the bilateral economic and security cooperation and in international organizations and regional affairs [11].

\subsection{Rebuilding Ties with Common Wealth Countries}

After the United Kingdom broke away from the many constraints of the EU's provisions, the United Kingdom refocused its attention on the relationship between the United Kingdom and the Commonwealth countries. The United Kingdom seeks to sign new trade agreements with Australia, New Zealand, Singapore, Canada and other 
countries to increase trade and contact with them. At the same time, the United Kingdom is also actively promoting the five defense agreements (the United Kingdom, New Zealand, Singapore, Malaysia, and Australia) to enhance military cooperation and intelligence sharing in the Asia-Pacific region. The UK will also actively develop trade with India and establish a free trade zone in Africa to promote trade between the UK and the African Commonwealth countries. Britain hopes to maintain the Economic Partnership Agreement (EPA) it signed with South Africa and other countries before Brexit and increased trade with African countries.

\subsection{Developing Relations with Major Emerging Economies}

The UK now also attaches great importance to developing relations with emerging economies, such as China and Brazil. The development of relations with these emerging economies is conducive to the prosperity of British foreign trade, including import and export. Economically, the UK hopes to attract investment in China and expand exports to China. In 2019, the bilateral trade volume between Britain and China exceeded US $\$ 86$ billion, a sharp increase from a decade ago. The two sides also have extensive cooperation in infrastructure construction. The United Kingdom has also cooperated with China to jointly deal with the North Korean nuclear issue at the political level. At the same time, the United Kingdom has expanded business exchanges with Brazil and launched the "British-Brazil Business Dialogue" to increase investment between the two parties. The United Kingdom also actively supports Brazil's accession to the Organization for Economic Cooperation and Development (OCED), responding to Brazil's reform initiative in the UN Security Council [12].

\section{THE UK-EU RELATIONSHIP: CHANGE AND TENDENCY}

In fact, Britain has always shown a half-hearted but uncooperative diplomatic attitude towards the EU in a certain sphere. Before joining the European Union, the United Kingdom believed in the tradition of splendid isolation to protect its own interests. After joining the European Union, the United Kingdom hopes to benefit from the EU's free trade market and mutually preferential policies. At the same time, Britain is deeply afraid of the harm of the EU integration to British national identity and the independence of the British domestic economy and foreign policy. Therefore, the United Kingdom has become an issue in the European Union and has many special exception arrangements in EU affairs. For example, the United Kingdom quickly withdrew after joining the European exchange rate mechanism and did not choose to join the Eurozone. The United Kingdom has not participated in the Schengen cooperation and will still use internal border inspections for citizens and goods entering the United Kingdom from Schengen countries The UK also refused to sign the 1989 Charter of Fundamental Social Rights of Workers in the European Community. Later, the UK refused to sign the 'Social Chapter' of the Maastricht Treaty. Although the UK, under the Labor Party government, later signed the 'Social Chapter', it still opposed the EU institutions and Germany's intention to incorporate the 'Social Chapter' into the EU treaty to give legal effects. Moreover, the United Kingdom once again asked for relevant special exception rights to protect the implementation and independence of its own labor law. Hence, the United Kingdom has not fully integrated into the various treaties of the European Union in common social policies [1315].

Britain has always viewed itself separately from the European continent due to the division of Britain by the English Channel and Britain's maritime expansion in the era of great voyages. Compared with European nations, many British people pay more attention to the "Anglo sphere of influence" model and the bond with the Commonwealth. At the same time, British culture still has an inseparable connection with Europe. The AngloSaxon nation has a deep blood connection with the European continent. The Roman invasion also brought the baptism of ancient Roman and Greek civilization to Britain. For example, Bath, a famous resort city in Britain, still has a huge bath from the Roman era. During the Renaissance and the Great Navigation Period, Britain also kept pace with Western European countries. Even later, relying on its own colonial resources and the rise of capitalism, it became the first country to initiate an industrial revolution in modern times, affecting the United States and European countries [16].

All in all, Britain and Europe have always had a mutual influence connection, and this connection will not easily disappear with Brexit. In the process of Brexit, both the United Kingdom and the European Union attach great importance to the content of the negotiations because both sides do not want to cause too much loss due to Brexit. Also, the two sides still need to cooperate in many aspects. According to the agreement, Britain and Europe can still carry out a "zero tariff, zero quota" trade method under the premise of complying with the standards of both parties. The formulation of laws in the United Kingdom has also been completely handed over to the British Parliament. It is no longer within the jurisdiction of the European Court of Justice. From this, we can see that the UK and the EU have made concessions in their agreements, which guarantees their own interests to the greatest extent and leaves space for the relationship between both parties. The EU and UK hope to establish and maintain mutual cooperation between the United Kingdom and the European Union to leave the European Union and promote the sustainable development of the bilateral relationship. 


\section{CONCLUSION}

In conclusion, the essay found that British exceptionalism and splendid isolation are prevalent in the history of the United Kingdom. The British have a sense of disapproval of the status of "European citizen". There is also a cultural gap between the United Kingdom and the European continent. The middle class was dissatisfied, and the British political parties took advantage of the trend to promote a referendum on Brexit for their own interests. Taking all factors into consideration, the outcome of this Brexit is not so surprising. After Brexit, the United Kingdom has also repositioned its international identity, tried to maintain its friendly relations with the United States, revitalized the long-term loose relationship between Commonwealth countries, and signed more trade agreements with emerging economies. This will give full play to their international influence and promote their own economic growth. Although the United Kingdom has left the European Union, both its status as a European country and its close proximity to the European continent make the United Kingdom's development still have important links with the European Union. In this Brexit negotiation, the EU and the United Kingdom have also used long-term negotiations and signed agreements to minimize the negative impact of Brexit on both sides. The United Kingdom will strive to promote cooperation with the European Union in a new, more independent, and friendly way.

The essay deepens our understanding of Brexit and helps us understand the future tendency of the EU-UK relationship. It provides policy recommendations to the UK and EU governments.

The essay has several limitations. The analysis may be incomplete, and maybe there are other reasons. The single case provides limited explanations and may not fully explain other cases.

Future studies can focus on other cases. Also, to fully understand the phenomenon, it is worthwhile to explore other perspectives and reasons. Finally, there is still room for research on the specific ways of international cooperation between the UK and the EU in the future.

\section{REFERENCES}

[1] Yang Fan, Yang Liu. The deep reasons for Brexit and the development prospects of the EU. New Vision, 2017(1): 115-121.

[2] BBC, n.d. EU Referendum. Retrieved on 25 September 2021 from: https://www.bbc.co.uk/news/politics/eu_referendu $\mathrm{m} /$ results
[3] Jin Ling. Brexit: Causes, Impacts and Trends. International Studies, 2016(4): 24-36, 131-132.

[4] Yang Yi. The three-dimensional challenge of Brexit to European integration. Theoretical Vision, 2016(8): 55-57.

[5] Chen Jie. From the perspective of Brexit, the EU's differential integration. International Forum, 2016(6): 13-18,77.

[6] Li Jingkun. Perspective of the social and political division of Europe from Brexit. People's Forum· Academic Frontiers, 2019(9):75-83.

[7] Feng Zhongping. Brexit and its impact on China. Modern International Relations, 2016(7): 1-6,62.

[8] Zhou Shuzhen and Sun Runnan. Suspended parliament, referendum and political structural issues of party politics-the political logic behind Brexit. Political Science Research, 2019(4): 212,125 .

[9] Zhang Biao. Global Britain: Britain's diplomatic choice after Brexit. Modern International Relations, 2018(3): 18-25,63-64.

[10] Zhao Huaipu. The relationship between Britain and Europe in the context of formal Brexit. Contemporary World, 2020(4): 57-63.

[11] Feng Cunwan. Building a new global role: An analysis of British diplomacy under the framework of Brexit. International Forum, 2018(4):37-43,77.

[12] Sun Shengnan, Gao Jian. "Global Britain" diplomatic concept and Britain's strategic choice. Contemporary World, 2020(4):64-71

[13] Pan Xingmin. New thinking on European integration - from the perspective of Brexit. People's Forum·Academic Frontiers, 2018(18):3444

[14] Liu Yan, Shi Jian. Studies on the relationship between the United Kingdom and Europe in the foreign academic circles-based on the perspective of future studies on the relationship between the United Kingdom and Europe. European Studies, 2016(3): 136-149, 168.

[15] Wang Zhanpeng. The Brexit referendum and the prospect of "multi-speed Europe". European Studies, 2016(4):35-42

[16] Gao Qiqi, Zhang Peng. The prospects of Britain's "Brexit" and European integration: an analysis of a new structural politics. Exploration, 2019(1): 79-91, 193. 